\title{
Antibacterial Potency of Pleurotus ostreatus Extract from Fruiting Body and Its Solid Substrate on Staphyllococcus aureus
}

\author{
I. Badarina ${ }^{a 1}$, D. Evvyernie ${ }^{b}$, E. N. Herliyana ${ }^{c}$, L. K. Darusman ${ }^{\text {d }}$, and T. Toharmat ${ }^{b}$ \\ ${ }^{a}$ Major Program of Animal Nutrition and Feed Science, Graduate School, Bogor Agricultural University \\ ${ }^{1}$ Departement of Animal Husbandary, Agriculture Faculty, Bengkulu University \\ ${ }^{b}$ Department of Nutrition and Feed Technology, Fac. of Animal Science, Bogor Agricultural University \\ ${ }^{c}$ Department of Silviculture, Fac. of Forestry, Bogor Agriculture University \\ ${ }^{\mathrm{d}}$ Departement of Chemistry, Faculty of Mathematics and Natural Science, Bogor Agriculture University \\ Corresponding email: irmabadarina@unib.ac.id
}

\begin{abstract}
The objective of this research was to evaluate the antibacterial potency of ethanol extract from fruiting body of Pleurotus ostreatus and Its solid substrate made from coffee husk and sawdust on the growth of Staphylococcus aureus ATCC 25922. The extract of Ganoderma lucidum fruiting body and Tetracycline antibiotic paper disk $30 \mu \mathrm{g} / \mathrm{disk}$ were used as control. The samples were extracted by using maceration method in $30 \%$ ethanol solution. The extracts were diluted with sterile distilled water to concentration 500, 1000, and $5000 \mathrm{ppm}$. The result showed that the ethanol extracts from fruiting body of Pleurotus ostreatus and Ganoderma lucidum and the extracts of coffee husk and sawdust substrate fermented by Pleurotus ostreatus could inhibit the growth of bacteria for all the concentration. There was a significant difference in diameter of cleared zones between Tetracycline antibiotic disc $30 \mu \mathrm{g}$ and the ethanol extracts of the samples $(\mathrm{p}<0.01)$. The diameter of cleared zones among the sample extracts and each dilution concentrations were not a significant difference $(\mathrm{p}>0.05)$. Tetracycline was sensitive to S.aureus ATCC25922, while all the extracts were resistant. This study confirmed that there were the antibacterial potency of mushroom extracts from the fruiting body and also its solid substrates.
\end{abstract}

Key words : antibacterial, extract, Pleurotus ostreatus, fruiting body, solid substrate.

\section{INTRODUCTION}

Mastitis is a major problem of the dairy animals. It is an inflammation of mammary gland parenchyme which is caused by bacteria and its toxins (Sharma et al., 2011). Mastitis influence the quantity and the quality of milk, be a food safety problem and an economic losses. The change of mammary tissues due to mastitis leading the progressive change to the secretory apparatus and resulting in the loss of milk production. The closed association between milk production and somatic cell count (SCC) has been increasing used to estimate production loss (Barlett et al., 1990). Mastitis changed milk composition and milk quality. The mastitis or elevated SCC is associated with a decrease in lactose, $\alpha$-lactalbumin, and fat in milk because of reduced synthetic activity of mammary tissue (Harmon, 1994). Milk from mastitis udder or with high SCC causes arise in whey protein and a decrease in casein, resulting in a considerable lower cheese yields. Shorter shelf life and adverse milk flavor are other consequences of high SCC (Sharif and Muhammad, 2008).

Several pathogens can cause mastitis but Staphylococcus aureus is the most frequently contagious pathogen. S. aureus secretes several toxins contributing to the pathogenesis of mastitis and also plays a role in foodborne disease, even with pasteurized milk because of the thermostable enterotoxins (Contreras et al., 2007). Because of that it is important to get the way to erradicate $S$. aureus in dairy animals.

The antibiotic usage is one of the way that often used to treat mastitis. But due to the growing concern of antibiotic resistance and residual effect to animals and humans, the use of antibiotic have already been banned or been minimized. A potential alternative to antibiotic is natural or traditional medicine and mushroom have been exploited for the treatment of many diseases. 
Mushrooms have been used as food supplement from times immemorial not only for their flavour, aroma and nutritive values but also for their medicinal properties as evident from ancient literature (Patel et al., 2012). The mushroom medicinal properties possess many typical pharmacological features like, to act as metabolic activators, prevent/control intoxication and microbial/viral infections, help in immunebalancing and immunomodulation, as antioxidants with rejuvenating and energy boosting properties (Wasser, 2002)

Mushrooms need antibacterial and antifungal compounds to survive in their natural environments. This antimicrobial compunds could be isolated from many mushrooms and that coul be of benefit for human (Lindequist et al., 2005). In the world of medicinal mushrooms, ganoderma is number one and has been considered as king of medicinal mushrooms followed by Lentinula and Pleurotus. The phytochemical or bioactive subtances have been documented such as saponin, alkaloid, flavonoid, triterpenoid and so on (Ijeh et al., 2009). The extract of the mushrooms were able to inhibit some pathogens including Staphylococcus aureus (Karaman et al., 2010).

The medicinal substances of mushroom can be found in fruiting body and mycelia (Stadtler \& Sterner, 1998; Martin et al., 2011). The mycellium can be grown in the solid state substrates in which generally come from lignocellulose wastes such as agro-industry byproduct including coffee husk and sawdust. Since Pleurotus ostreatus has the biopotentialities to bioconversion of lignocellulosic wastes and production or improved animal feed, research concerning the use of solid fermentation substrate to produce bioactive compounds also interested to be explored. The use of agro-industry residues through solid state fermentation provides an important way to overcome environmental problems caused by their disposal, and being an economic way for production of value added compounds. The aim of this research work was to explore potentiality of Pleurotus ostreatus extract from fruiting body and its solid substrate on the growth of Staphylococcus aureus in vitro.

\section{MATERIALS AND METHODS}

\section{Preparation of Extraction}

The four samples consisted of fruiting body from Pleurotus ostreatus and Ganoderma lucidum, full mycellium of solid substrate from coffee husk and sawdust fermented by Pleurotus ostreatus were dried and pulverized into fine powder. The composition of solid substrate from coffee husk dan sawdust listed in Table 1. The ethanol extracts were prepared using the maceration. The powdered samples were macerated in the $30 \%$ ethanol solution with the ratio samples to solution $=1: 3$. The suspensions were stirred and precipitated overnight then be refined. The supernatants were retained while two further similar extractions were carried out. The three supernatants were combined and the residue was discarded. The supernatants were dried in vacuum rotavapor at $50^{\circ} \mathrm{C}$ to obtain the concentrate extracts. The extracts were diluted in sterile distilled water to obtain the concentration 500ppm, 1000ppm and 5000ppm for antibacterial test.

\section{Preparation of Bacterial Culture}

The bacterial culture was prepared according to the method of Tilton et al. (1989) with a slight modification. The stock culture of bacterial colony used were Staphylococcus aureus (ATCC 25922). The stock culture of bacterial on growing nutrient agar media were taken and suspended into $5 \mathrm{ml}$ sterile saline solution. When the turbidity of about $9 \times 10^{8}$ bacterial cells $/ \mathrm{ml}$ (equal to Mc. Farland no.III standard) was attained, the cell suspensions were diluted in sterile saline solution to obtain a concentration of $9 \times 10^{6}$ bacterial cells $/ \mathrm{ml}$ for further antibacterial test.

\section{Antibacterial Test}

Antibacterial testing was done by using agar diffusion paper disk method as described by Cowan and Steel (1989). As much as $20 \mathrm{ml}$ sterile Mueller Hinton agar was poured into a petri dish. As much as $1 \mathrm{ml}$ bacterial suspensions $9 \times 10^{6}$ cells $/ \mathrm{ml}$ was spread over the surface of agar plates, and the dishes were incubated at temperature room for 15 minutes. 
As much as three sterile blank papers disk were immersed into the extract solution that had been diluted (500ppm, 1000ppm dan $5000 \mathrm{ppm}$ ) for five minutes. The papers disk were then be placed on the surface of agar media. The tetracycline paper disk $30 \mu \mathrm{g} /$ disk were used as a positive control. All experiments were performed in triplicate. After incubation at $37^{\circ} \mathrm{C}$ for 18-24 hours, the diameter of cleared zones was measured in milimeter ( $\mathrm{mm})$. The antimicrobial activity was evaluated by measuring the diameter of cleared zone. The cleared zone was a tranparent zone formed around the paper disk showed bacteriostatic activity.

\section{Phytochemical Properties of the Extracts}

The obtained extracts were examined for the presence of alkaloids, flavonoids, phenol hidroquinon, steroids, triterpenoids, tannin, and saponin as described by Harborne (1989).

Table 1. The composition of coffe husk solid substrate and sawdust solid substrate

\begin{tabular}{lccccc}
\hline Solid substrate & Coffee husk (\%) & $\begin{array}{c}\text { Saw dust } \\
(\%)\end{array}$ & $\begin{array}{c}\text { Rice bran } \\
(\%)\end{array}$ & Gips (\%) & $\begin{array}{c}\mathrm{CaCO}_{3} \\
(\%)\end{array}$ \\
\hline Coffee husk & 82.5 & - & 15 & 1.5 & 1.0 \\
\hline Sawdust & - & 82.5 & 15 & 1.5 & 1.0 \\
\hline
\end{tabular}

Source : Badarina et al. (2013)

\section{Statistical Analysis}

A completely randomized design with four extract samples and three dilution concentrations was used. The trials were in triplicate. Data were subjected to one-way analyses of variance (Steel and Torrie, 2003).

\section{RESULTS AND DISCUSSION}

The diameter of cleared zones from ethanol extract of P.ostreatus and Ganoderma lucidum fruiting body and full mycellium of solid substrate from coffee husk and sawdust fermented by Pleurotus ostreatus were presented in Table 2. The result showed that there was a tranparent zone or cleared zone surroundings the paper disk on the concentration 500, 1000 and $5000 \mathrm{ppm}$ respectively. This condition indicated that there was antibacterial activity from ethanol extract of the samples on Staphylococcus aureus (ATCC 25922).

This research showed that the diameter of cleared zones of ethanol extracts in all concentrations formed by mushrooms were smaller than tetracyclin $30 \mu \mathrm{g} / \mathrm{disk}(\mathrm{p}<0.01)$. There was no significant difference $(\mathrm{P}>0.05)$ among the samples of ethanol extracts and the concentration of the extracts in the diameter of cleared zones. This condition implied that the mushroom ethanol extracts from each sources had the same ability in antibacterial activity.

Tetracyclin included the one of broad spectrum antibiotics. The diameter of cleared zones or inhibiting zone according to NCCLS (National Committee for Clinical Laboratory Standard) with $<14 \mathrm{~mm}$ was resistance, $15-18 \mathrm{~mm}$ was intermediate and $>19 \mathrm{~mm}$ was sensitive (Cowan and Steel, 1989).

Table 2. The diameter of cleared zones on Staphylococcus aureus ATCC 25922 from ethanol extract of P.ostreatus and Ganoderma lucidum fruiting body and full mycellium of solid substrate from coffee husk and sawdust fermented by Pleurotus ostreatus

\begin{tabular}{lccc}
\hline \multirow{2}{*}{ Samples } & \multicolumn{3}{c}{ The concentration of ethanol extracts } \\
\cline { 2 - 4 } & $500 \mathrm{ppm}$ & $1000 \mathrm{ppm}$ & $5000 \mathrm{ppm}$ \\
\hline Tetracyclin & $30.98 \pm 0.86$ & $31.13 \pm 0.47$ & $31.73 \pm 0.24$ \\
P. ostreatus & $9.17 \pm 0.49$ & $10.05 \pm 3.15$ & $15.07 \pm 5.92$ \\
Ganoderma lucidum & $8.12 \pm 0.88$ & $8.23 \pm 2.08$ & $10.45 \pm 0.95$ \\
Coffee husk & $7.88 \pm 3.043$ & $8.95 \pm 1.51$ & $8.70 \pm 0.16$ \\
Sawdust & $8.43 \pm 1.15$ & $8.38 \pm 1.21$ & $8.02 \pm 1.11$ \\
\hline
\end{tabular}

This research showed that the tetracyclin antibiotic was sensitive to Staphylococcus aureus ATCC 25922 while the ethanol extracts from mushrooms in this research had weak antibacterial activites. The diameter of transparent zones in this research were in 7- 
$15 \mathrm{~mm}$. This condition was possibility because the samples extracts were still in crude extract. Kalyoncu et al. (2010) reported that the spectrum of biological activities of mushroom is very broad. The maximum antibacterial effect to $S$. aureus in tested macrofungi was shown by P.ostreastus as $24 \mathrm{~mm}$. The least active was shown by species were Morchella elata, Morchella esculenta, P.eryngii and Paxillus involutus as $8 \mathrm{~mm}$. They recommended to obtain the wider antibacterial effect, further works could be done on the isolation and purification of biological active component from crude extract.

Antibacterial effect exhibited by fungal extracts could be related to its pharmacologically bioactive substances. The phytochemical screening from the sample extracts are presented in Tabel 3.

Table 3. Phytochemical properties of fruiting body extracts of P.ostreatus, G.lucidum and the extracts of coffee husk and sawdust substrates fermented by P.ostreatus

\begin{tabular}{lcccc}
\hline Phytochemical properties & $\begin{array}{c}\text { Ganoderma } \\
\text { lucidum }\end{array}$ & $\begin{array}{c}\text { Pleurotus } \\
\text { ostreatus }\end{array}$ & Coffee Husk & Sawdust \\
\hline Alkaloid & ++ & ++ & +++ & - \\
Flavonoid & + & + & ++ & +++ \\
Phenolhidroquinon & + & - & + & + \\
Steroid & - & - & - & - \\
Triterpenoid & + & + & + & + \\
Tanin & ++ & - & ++ & - \\
Saponin & +++ & - & +++ & ++ \\
\hline
\end{tabular}

The pharmacologically bioactive substances that have great therapeutic significance produced by macrofungi were the secondary metabolites (Table 2). Flavonoid and triterpenoid were found in all samples extracts. While steroid was not detected at all. Saponin were found in the extracts of Ganoderma lucidum fruiting body, coffee husk and sawdust fermented substrate. Alkaloid wasnot found in sawdust fermented extract. Fermented coffee husk extract were rich in alkaloid. Tannin were found in Ganoderma lucidum and coffe husk fermented substrate. From the phytochemical properties screening, the extracts of Ganoderma lucidum and coffee husk fermented by P.ostreatus contained the bioactive substances in higher contrentration than others.

The production of certain secondary metabolites may depend on the characteristics of the strain or culture condition. The precise composition of examined extracts of fungi is unknown and can only be assumed that the effect of crude extracts, which are concentration dependent, is a consequence of complex interactions between cells and mixtures of compounds in the extracts (Karaman et al., 2009). Coffee husk subtrate fermented by P.ostreatus showed a great potency in phytochemical contents. Coffee husks were rich in phenolic compound (tannin, saponin, flavonoid) and Alkaloid (caffeine) (Bressani, 1979; Fan et al., 2000; Badarina et al., 2013).

These compunds have the antibacterial activity. Cowan (1999) said that the presence of phenol hydroxyl groups has the correlation to antimicrobial activity. Antimicrobial properties of phenolics are explained by the presence of phenol hydroxyl groups, which number is in correlation with their toxicity toward microorganisms. Caffeine is an alkaloid named trimethylxanthine that often used for its medicinal properties (Nolan 2001: Hosseinzadeh et al. 2006). Charles and Rawal (1977) said that caffeine could inhibit the growth of Staphylococcus by inhibiting Staphylococcus penicillinase enzyme.

The result of this study confirmed that there were the antibacterial potency of mushroom extracts from fruiting body and also its solid subtrates. Further study with more focus on the isolation and purification of biological active component from crude extract was therefore suggested.

\section{ACKNOWLEDGMENT}

This work was supported by research fund of DP2M Dikti through Hibah Bersaing with research agreement no: $256 / \mathrm{h} 30.10 / \mathrm{pl} / 2011$ on date April $20^{\text {th }} 2011$. 


\section{REFERENCES}

Badarina, I., D. Evvyernie, T. Toharmat, E. N. Herliyana, and L. K. Darusman. 2013. Nutritive value of coffee husk fermented with Pleurotus ostreatus as ruminant feed. Media Peternakan 36 (1): 58-63. DOI; 10.5398/medpet.2013.36.1.58.

Barlett, P. C., G. Y. Miller, C. R. Anderson, and J. H. Kirk. 1990. Milk production and somatic cell count in Michigan Dairy Herds. J. Dairy Sci. 73: 2794-2800.

Bressani, R. 1979. Antiphysiological factors in coffee pulp. Coffee Pulp: Composition, Technology and Utilization. IDRC Pub. $108,1979$.

Charles, B. G. And B. D. Rawal. 1977. Action of caffeine and theophylline on Staphylococcal penicillinase synthesis. Chemotherapy 23: 452-457.

Contreras, A, D. Sierra, A. S'anchez , J. C. Corrales, J. C. Marco, M. J. Paape, and C. Gonzalo. 2007. Mastitis in small ruminants. Small Rum. Res. 68:145-153.

Cowan, S. T. and K. J. Steel. 1989. Manual for the Identification of Medical Bacteria 2nd Ed. Cambridge University Press. Cambridge, London, New Rochelle.

Cowan, M. M. 1999. Plant products as antimicrobial agents. Clinical Lindequist, U., Niedermeyer, T. H. J. and Julich, Microbiologicy Reviews. 12 (4): 564-582.

Fan, L., A. Pandey, R. Mohan, and C. R. Soccol. 2000. Use of various coffee industry residues for the production of Pleurotus ostreatus in solid state fermentation. Acta Biotechnol. 20 (1): 41-52.

Harborne, J. B. 1989. General procedures and measurement of total phenolics. In J. B. Harborne (Ed.). Methods in plant biochemistry: Volume 1 Plant Phenolics (pp. 1-28). London: Academic Press.

Harmon, R. J. 1994. Physiology of mastitis and factors affecting somatic cell counts. J. Dairy Sci. 77:2103-2112.
Hosseinzadeh, H., B. Sedigheh, F. Bazzaz, M. M. Sadati. 2006. In vitro evaluation of methylxanthines and some antibiotics: Interaction against Staphylococcus aureus and Pseudomonas aeruginosa. Iranian Biomedical Journal 10:163-167.

Ijeh, I. I., A. I. Okwujiako, C. P. Nwosu, and H. I. Nnodim. 2009. Phytochemical composition of Pleurotus tuber regium and effect of its dietary incorporation on body/organ weights and serum triacylglycerols in albino mice. J. Med. Plant. Res. 3:939-943.

Kalyoncu, F., M. Oskay, H. Sağlam, T.F. Erdoğan, and A.U. Tamer. 2010. Antimicrobial and antioxidant activities of mycelia of 10 wild mushroom species. J. of Med. Food 13 (2): 415-419.

Karaman, M., E. Jovin, R. Malbaša, M. Matavuly, and M. Popović. 2010. Medicinal and edible lignicolous fungi as natural sources of antioxidative and antibacterial agents. Phytotherapy Research 24 (10) : 14731481.

Karaman, M., Mimica-Dukić, N., Knežević, P., Svirčev, Z., Matavulj, M. 2009. Antibacterial properties of selected lignicolous mushrooms and fungi from northern Serbia. International Journal of Medicinal Mushrooms 11(3): 269-279.

W. D. 2005. The Pharmacological potential of mushroom. Evidence-based Complementary and Alternative 2 (3): 285-299. http://dx.doi.org/10.1093/ecam/neh107

Martins, S., S.L. Mussatto, G.Martinez-Avilla, J.Montanez-Saenz, C.N.Aguillar, \& J.A. Teixeira. 2011. Bioactive phenolic compounds: Production and extraction by solid-state fermentation. A review. 
Biotechnology Advances. 29: 365-373. Sharma, S. G., M. Fatma, and V. K. Singh. 1996. doi: 10.1016/j.biotechadv.2011.01.008.

Nolan, L. 2001. The world's favorite beverage coffee and health. Journal of Herbs, Spices \& Medicinal Plant. 8:119-159.

Patel, Y., R. Naraian, and V. K. Singh. 2012. Medicinal properties of Pleurotus species (Oyster mushroom): A Review. World Journal of Fungal and Plant Biology 3: 01- Steel, R. G. D. and J. H. Torrie. 2003. Principles 12.

Sharif, A. and G. Muhammad. 2008. Somatic cell count as an indicator of udder health status under modern dairy production: A review. Pakistan Vet. J. 28 (4):194-200.

Sharma, N., N. K. Singh, and M. S. Bhadwall. 2011. Relationship of somatic cell count Wasser, S. P. 2002. Medicinal mushrooms as a and mastitis: An overview 24 (3): 429-438.

Stadtler, M. And O. Sterner. 1998. Production of bioactive secondary metabolites in the fruit bodies of macrofungi as a response to injury. Phytochemistry 49 (4) :1013-1019. and Procedures of Statistics. 2 ed. Mc. Graw-Hill Book Co. Inc., New York.

Tilton, R.C., A. Vaheri, and A. Balows. 1989. Rapid methods and automation in microbiology and imunology. Raven Press, New York.

Biochemical changes during solid substrate fermentation of water hyacinth with Pleurotus sajorcaju. Mush. Res. 5: 89. source of antitumor and immunomodulating polysaccharides (minireview). Appl. Microbiol. Biotechnol., $\quad$ 60: 258-274. 